Marta Śliwa

University of Warmia and Mazury, Olsztyn, Poland

ORCID: 0000-0001-8796-511X,

e-mail: marta.sliwa@uwm.edu.pl

\title{
Philosophical Societies in the Scottish Enlightenment
}

DOI: http://dx.doi.org/10.12775/RF.2018.030

In the study, the role played by philosophical societies in the $18^{\text {th }}$ century Scotland is analysed. A special attention is focused on the activity of two opposing societies: on the one side there is the Aberdeen Philosophical Society and, on the other, the Philosophical Society of Edinburgh. To present them and the role they played, the socio-cultural environment in which such an exceptional phenomenon could exist should to be described.

In the $18^{\text {th }}$ century Scotland, the Parliamentary Union of 1707 created a unique situation resulting from significant development and improvement of both the economic and cultural conditions. The Scottish Enlightenment is commonly defined as an intellectual spark following a process of intellectual accumulation and dissemination, which "took place in and only made sense in an extended social arena". ${ }^{1}$ In the Scottish context, the notion of Enlightenment can be further expanded to include a powerful desire for "improvement", and thus, this intellectual movement is called the Scottish 'Age of Improvement'. The "high period" of Scottish Enlightenment took place between 1730 and 1800 and had a few key characteristic features. The development of the science of human nature and natural philosophy was one of them. Roger Emerson claims that people of that Age "believed that rational-grounded

1 David Allan, Making British Culture: English Readers and the Scottish Enlightenment, 1740-1830, Routledge Studies in Cultural History, 8, (London: Routledge, 2008), 239. 
natural knowledge could be found and was to be sought". ${ }^{2}$ This scientific activity, rooted in natural sciences, together with the introduction of a 'distinctive philosophical and educational programme' in schools and universities, and openness to knowledge in Scottish society were part of that Enlightenment, unique for Scotland. A crucial role in the cultivation of natural sciences was played by universities, clubs, and "improving", specialized, societies.

There were four universities in Scotland that time, i.e. St. Andrews, Glasgow, Aberdeen, and Edinburgh providing non-residential and relatively inexpensive higher education. By the mid- $18^{\text {th }}$ century, many contemporaries felt that the Scottish universities were offering the best higher education in the British Isles. ${ }^{3}$ The main reason for that was a connection between practical and traditional classical education.

In 1708, the University of Edinburg ended its regent system in which professors taught the entire curriculum. That was a major change and, at the same time, some new university chairs were created, e.g. separate chairs of civil law, public law, and Scottish law. Also, universal civil history was separated from ecclesiastical history. By 1730, lawyers and physicians were educated in Scotland, which contributed to perception of the Scottish universities as very modern ones. ${ }^{4}$ It can be noticed that many of Scottish men of science were somehow connected with universities, and most of them were university professors. A lot of effort was made to provide the best scientists for each faculty; the medical school in Edinburgh was a good example of that practice: two brilliant chemists, William Cullen and Joseph Black, were lured away from Glasgow. In the 1760s, Edinburgh was known as "Athens of the North". ${ }^{5}$

The clubs and societies played a particular role in the Scottish Enlightenment. The activities of societies of Edinburgh, Aberdeen, and Glasgow were essential characteristic of the intellectual, social, and cultural life. The Scottish men of science belonged to one or more of the societies, and so did their readers. The tradition of organizing debates, discussions and cooperative inquiries which took place at the meetings of the societies continued after them as mail exchange greatly affected individual achievements of their members. At the philosophical scene,

2 Roger L. Emerson, "Science and the Origins and Concerns of the Scottish Enlightenment," History of Science 26, (1988): 338.

3 See more: Hilde De Ridder-Symoens, A History of University in Europe: vol. II Universities in Early Modern Europe (1500-1800), (Cambridge: Cambridge University Press, 2003).

4 Roger L. Emerson, Essays on David Hume, Medical Men and Scottish Enlightenment: Industry, knowledge and Humanity, (London: Routledge, 2016), 46.

5 Willis Rudy, The Universities of Europe, 1100-1914. A History, 1920 (Associated University Press, 1984), 77-99. 
at least David Hume, Adam Smith, Thomas Reid, and Alexander Gerard should be mentioned. So, such societies became a place for presenting new ideas, and, at the same time, for their reception and application. The scientists of those days knew one another, and were sometimes close friends.

Edinburgh was a great example of such diversity. The Honourable Society of Improvers in the Knowledge of Agriculture in Scotland (1723) and the Edinburgh Musical Society (1726), the Society for the Improvement of Medical Knowledge, known as the Medical Society (1731) and the Student Club (1734), all of them, as Emerson writes: "were ones in which learning, patriotic sentiment, politeness, and improvement joined in the mind of members, often recruited from disparate backgrounds, who sought through associations to promote good for the kingdom" ${ }^{6}{ }^{6}$ Different social backgrounds and approaches of those societies can immediately be seen. Members varied significantly as the societies invited both men of science (from universities and professions) as well as nonprofessional enthusiasts representing different social groups: gentlemen with estates but also farmers, women and printers such as Ruddiman. The societies were different in their approach to science: some focussed on more theoretical issues and concentrated on debates, formal lectures, discussion of questions asked by members, some were more practical, focussing on promotion and implementation of knowledge in the Scottish society. Some of these clubs concentrated more on socialisation, but many of them combined both, scientific and social aims.

As it can be seen above, the main idea set by those specialized societies was the same: modernization - a programme based on improving everything (from music, manners, philosophy, natural sciences), which could make Edinburgh and the whole Scotland develop into a modern society. In this truly enlightened approach, discussions on religion and politics was consciously avoided. Things that Emerson emphasises include liberal conversations, politeness, urbanity, clarity of style, accuracy of reasoning, awareness of the intellect, and making activities outside the Scotland better. All these were promoted by the discussed groups. ${ }^{7}$ The diversified membership (amateurs, landowners) allowed the knowledge to spread and be updated within the country. The uniqueness of Scottish Enlightenment is deeply connected with 'learned societies with a cosmopolitan approach' which was the result of the social activity of single members of societies, shortening the distance to the main centres of knowledge, and, at the same time, making local groups part of sci-

6 Roger L. Emerson, “The Philosophical Society of Edinburgh 1737-1747," The British Journal of History of Science 12, no. 2 (July 1979): 157.

7 Ibidem, 158-159. 
entific society. This seems to be a vital factor of the Scottish "Age of Improvement".

Thus, those societies, very different in character, played an important role in supporting and implementing the ideas and goals of the Enlightenment. This study is to explain how it was done on the basis of some specialized philosophical societies.

\section{The Aberdeen Philosophical Society}

It is good to start with one of the most scholarly and exclusive society the Aberdeen Philosophical Society, commonly known as the Wise Club. Its activity is very well documented. ${ }^{8}$

The Wise Club met every second and fourth Wednesday of a month at $5 \mathrm{pm}$ between 1758 and 1773, alternately at one of two taverns, for a three-hour session of conversation and supper. It was Thomas Read who was its driving force and its first meeting took place on the $12^{\text {th }}$ January 1758. The six founding members were George Campbell (1719-1796), Professor of Divinity and Principal, Marischal College, Aberdeen; Thomas Reid (1710-1796), Regent, King's College, Aberdeen, later Professor of Moral Philosophy, Glasgow; John Stewart (c. 1708-1766), Professor of Mathematics, Marischal College; Robert Trail (1720-1775), Professor of Oriental Languages, later Professor of Divinity, Glasgow; John Gregory (1724-1773), Professor of Philosophy, King's College, later a mediciner at King's Collage; David Skene (1731-1770), a physician, Dean of Faculty in Marischal Collage. Very shortly afterwards, another nine elected members were invited to join the group. These were John Farquhar (1732-1768), a Scottish Church minister; Alexander Gerard (1728-1795), Professor of Logic and Moral Philosophy, Marischal College, later Professor of Divinity, King's College; Thomas Gordon (1714-1797), Professor of Humanity, King's College; John Ross (c. 1730-c. 1800), Professor of Hebrew, King's College; James Beattie (1735-1803), Professor of Philosophy and Logic, Marischal College, a philosopher and a poet; William Ogilvie (1736-1819), Professor of Philosophy, later Professor of Humanity, King's College; James Dunbar (1742-1798), Regent, King's College; William Trail (1746-1831), Professor of Mathematics, Marischal College,

8 Lewis H. Ulman in Minutes of the Aberdeen Philosophical Society presented the $18^{\text {th }}$ century Aberdeen with the special role played by the Wise Club. The history of the Society was documented by original records, including: The Rules of The Philosophical Society in Aberdeen, The Minutes, List of Questions, transaction of the Wise Club. Minutes of the Aberdeen Philosophical Society, 1758-1773, ed. by Lewis H. Ulman, Aberdeen University Studies Aberdeen University Studies, 158. Aberdeen: Aberdeen University Press, 1990. 
later Church of Ireland minister; George Skene (1742-1803), Professor of Natural Philosophy, later Professor of Civil and Natural History, Marischal College, and a physician.

Members for the Wise Club were chosen on the basis of their scholarly experience, and that hugely affected the procedure and topics of its meetings. The club was exclusive: it run for fifteen years and the number of its members was never higher that fifteen. The rules of participation were strictly defined. Each member had to read a major 30-minute-long discourse every year and had to prepare questions for the debate. The list of questions, being a part of the Minute Book of the society, was always available for study. The members had to discuss their own questions and summarize the debate. ${ }^{9}$ The idea was to encourage an active exchange of thoughts and new theses. As the Society members read and discussed philosophical dissertations and discourses, they expected criticism from their colleagues. Some of the questions and the papers read out at the meetings were directly published by the members, which is well documented; a small part of that is shown below in Thomas Reid and Alexander Gerard's activity in the Wise Club.

\section{Thomas Reid in the Wise Club}

Kathleen Holomb in her book The Philosophy of Thomas Reid stressed Dugald Stewart's opinion on Reid's modesty or lack of confidence and the fact that, without some encouragement from his friends in the Aberdeen Philosophical Society, he would not be able to publish the Inquiry. ${ }^{10}$ Reid understood very early that the Society itself could have such an encouraging function. As Lewis Ulman points out, he learned from the disagreement within the debates and used this to improve his theories. He definitely profited from debates, for example he presented part of the Inquiry connected with the sensation. The order in which the senses are discussed was altered and major changes were made to the chapter on sight. In the original Discourse, Reid explained why he, at first, began the sensation part of the Inquiry with sight: "The perceptions we have by the external senses seem to be the first, the simplest, \& the most distinct operations of the mind, \& therefore proper to be first considered in an analysis of it. I shall therefore at this time make some observations on the

9 See: "Minute Book of Society" in: Minutes of the Aberdeen Philosophical Society, 1758-1773, ed. by Lewis H. Ulman, Aberdeen University Studies 1990, 73-198; “List of Questions", 189-198.

10 Kathleen Holcomb, "Reid in the Philosophical Society" in The Philosophy of Thomas Reid, ed. Melvin Dalgarno \& Eric Matthews (Kluwer Academic Publishers, 1989), 413. 
perceptions we have by sight" (MS 3107/1/1/p.19 (14 June, 1758)). ${ }^{11}$ But, in next Discourse, we can read: "The order in which sensations are to be considered, is by giving precedence, not to the noblest \& most useful, but to the simplest \& those whose objects are least in danger of being mistaken for other things-\& may be as follows: Smelling, tasting, hearing, Touch, \& last of all Sight" (MS 3107/1/3/p.58 (14 March, 1759)). ${ }^{12}$

\section{Alexander Gerard in the Wise Club}

Two $18^{\text {th }}$ century societies in Scotland, i.e. the Wise Club and the Edinburgh Society for Encouragement of Arts, Sciences, Manufactures, and Agricultures, played noticeable roles in the development of the aesthetic theory of Gerard.

In 1755 , the latter society awarded a medal for the best essay on taste to Alexander Gerard. It was at the Wise Club's meetings taking place between 1758 and 1771 when Gerard presented papers on genius, as well as a paper on the effect of passions on the association of ideas. On the $22^{\text {nd }}$ April 1758, John Farquhar suggested discussing the questions: "In the perfection of what faculty does genius consist? Or if in a combination of faculties, what are they?" The questions started a heated discussion, with Thomas Reid and John Gregory criticizing Gerard, which is evidence of a great interest in that subject among members of the Society. That resulted in Gerard's Essay on Genius in which the answer to that question can be found: the power of imagination is the true origin of genius. ${ }^{13}$

As can be seen in this short analysis, the Wise Club presented mainly an 'inner' activity of their members, focused on a deeply scholarly aims.

\section{The Phiilophical Society of Edinburgh}

An outstanding example of a society focused more on social aspects is the Society of Improving Arts, and Science and particular Natural Knowledge, commonly known as the Philosophical Society of Edinburgh. For the purposes of this study, this society is contrasted with the Aberdeen Wise Club, as it was less scholarly but more socially oriented.

After the solar eclipse observed on the $18^{\text {th }}$ February 1737 and a comet visible in the sky in April that year, an increase of interest in natural philosophy was noticed. That directly led to establishing the Philosophical Society of Edinburgh (PSE). The beginning of the PSE is related to the

11 Ibidem, 416.

12 Ibidem, 417.

13 Margaret Lee Wiley. "Gerard and the Scots Societies," Studies in English, no 20 (1940): 134. 
Society for the Improvement of Medical Knowledge which was founded in 1731 by Alexander Monro and thirteen other Edinburgh doctors. After the suggestion made by Collin MacLurin concerning the extension of the Medical Society into a more general learned society, in June 1737, the Philosophical Society of Edinburgh was established. Among the founders of the PSE were some men associated with astronomy; nine astronomers were also invited to the meeting in which the PSE was established. That shows how broadly the term "philosophy" was defined. So it is not surprising that the newly established Society got involved in fields such as natural philosophy as well as medicine, natural history, and antiquities. Even so, throughout the whole existence of the Society, special attention was paid to medicine and Newtonian physics.

The PSE is perceived as a perfect example of an enlightened society, including both Edinburgh professors (predominantly) and non-professional enthusiasts who played an important role in spreading the knowledge into local communities, which simultaneously gave them some special prestige. The Society became the pride of Scotland also because of its international contacts. It was seen as having roots in Scottish science, but, at the same time, Edinburgh men of science looked for inspiration abroad - from the world's enlightened ideologies, institutions, and other societies. ${ }^{14}$

Roger Emerson analysed the history of the PSE in detail, splitting his research into the three periods of the society's existence.

In the first decade, the social role of the Society is mirrored in its inner diversity of backgrounds and profession. In 1739, the first 46 Scottish members of the PSE were usually well-educated and well-travelled professionals, in possession of land. It was rather an aristocratic group (nine of them were landowners and only two members came from poorer families). Twelve were advocates, eleven - doctors, four - surgeons, four - soldiers, two - clergymen, two - professors, an architect, a printer, a librarian, an optician and instrument maker, an iron master, and a manager of a mining company (as for the six others, the occupation is not known).

Also, in that era, scientific interests of Edinburgh were reflected in the debates held at the Society. The following analysis presents the topics discussed in the PSE between 1737 and 1747: medicine - 7 topics, 10\% of the total number; astronomy -6 topics, $8 \%$; mining -3 topics, $3 \%$; technology -3 topics, $4 \%$; physics -4 topics, $6 \%$; mathematics -6 topics, $8 \%$; history and antiquaries -7 topics, $10 \%$; biology -3 topics, $4 \%$; chemistry -7 topics, $10 \%$; meteorology -1 topic, $1 \%$; mapping -6 topics,

14 Roger L. Emerson, “The Philosophical Society of Edinburgh 1737-1747," The British Journal of History of Science 12, no. 2 (July 1979): 171. 
$8 \%$; agriculture and improvements -1 topic, $1 \%$; geology -1 topic, $1 \%$, botany -1 topic, $1 \%$.

It is worth presenting some achievements of that decade:

- two volumes of Medical Essays and Observation and Literary, edited by Alexander Monro, published by the Society of Edinburgh from 1732; a very successful publication with the original intention claiming "that Histories might be extracted from the Register" and supplied with commentaries; later, its scope was extended: the topics covered the meteorological record of Edinburgh weather, essays on history, theory and practice of medicine and surgery with accounts of newly devised instruments and operations (it was read by medical societies members throughout Europe as its French translation was also available from 1733 to 1736);

- novelties and technological information related to mining were spread among members of the Society;

- astronomical observation made in Edinburgh were printed in the Philosophical transactions of the Royal Society in London;

- the Stirling engine was discussed;

- several maps of the coast were improved.

To sum up, it can be said that the first decade of the PSE activity brought the expression of enlightened ideas of that newly forming Society based on a combination of theory and practice. ${ }^{15}$

The Society's recruitment rules changed within the second and third decade of its activity: more academics were admitted, including philosophers, which proves a more scientific turn in its activities. The analysis of the known topics discussed in the PSE for the years 1748-1768 shows the following: medicine -62 topics, $54 \%$ of total number; astronomy 2 topics, $2 \%$; mining -2 topics, $2 \%$; technology -5 topics, $4 \%$, physics 7 topics, $6 \%$; chemistry -9 topics; $8 \%$; meteorology -1 topic; $1 \%$; mapping - 0; agriculture and improvements -6 topics, $5 \%$; geology -3 topics; $4 \%$; botany -5 topics, $4 \%$. As it may be seen, medical, chemical, agricultural, and physical topics seemed to dominate the Society's work. However, those are not only its papers and discussions that prove the importance of the PSE. It fulfilled a social function as a reference group and a certifying agency, which provided affiliation for a number of young men with their careers in Scotland and beyond. In its early years, the Society helped to institutionalize the scientific movement in Scotland and to make natural philosophy more acceptable, useful, and appreciated. Later, the Society made it possible to bring together men in need of patronage and the ones able to provide it. It is stipulated that the Society sponsored Adam Smith's lecturing on belles letters in Edinburgh from

15 Ibidem, 154-191. 
1748-1751. That was the time when an intensification of international contacts was visible in the Society's activities. ${ }^{16}$

The years 1768-1783 are the time when Henry Home, Lord Kames, held the post of the Society President. It was during his Presidency, in 1773, when Andrew Duncan and the Society began publishing Medical and Philosophical Commentaries. The journal may be perceived as the main achievement of the Society at that time as it facilitated exchanging information with foreign members of the Society or non-resident Scots. By 1780, Duncan regularly had received letters from all over the world, including India, Russia, Europe, the West Indies, and Africa. On a regular basis, the journal delivered reports on the latest issues discussed at the Society's meetings.

As for the years 1768-1783, the analysis of the topics discussed in the PSE looks as follows: medicine -5 topics, $12 \%$ of total number; astronomy -1 topic, $2 \%$; mining - 0; technology -9 topics, $22 \%$; physics -7 topics, $6 \%$; mathematics -0 ; chemistry -6 topics, $15 \%$; history \& antiquaries -1 topic, $2 \%$; mapping -0 ; meteorology -5 topics, $12 \%$; agriculture \& improvements -2 topics, $5 \%$; geology -0 ; botany -5 topics, $7 \%$. As it can be seen, technical, chemical, physical, and, what is new, botanical topics seemed to dominate the Society work that time. ${ }^{17}$

The end of the PSE is linked with founding the Society of Antiquaries of Scotland (1780) and a final transformation of the PSE into the Royal Society of Edinburgh (1783), in which natural sciences were still cultivated but more with social or even political rather than scientific bias. ${ }^{18}$

Nevertheless, it is worth remembering how the Society was perceived by the contemporaries. In 1778, William Cullen wrote in the Memorial for the Philosophical Society of Edinburgh: "The Philosophical Society of Edinburgh was formed with most excellent design of promoting Natural Knowledge, and of doing credit to the Genius and Scientific industry of the country". ${ }^{19}$ Lord Kames himself defined the Society in the following way: "Skill and patriotism among members, punctuality and regular attendance at meeting, zeal in the promotion of the search for and application of knowledge and an impartial regard for merit." 20 Those words summarize the genuine enlightened character of the Philosophical Society of Edinburgh.

16 Roger L. Emerson. “The Philosophical Society of Edinburgh 1748-1768," The British Journal of History of Science 14, no. 2 (July 1981): 133-176.

17 Roger L. Emerson, "The Philosophical Society of Edinburgh 1768-1783," 255-303.

18 See more idem Emerson, "The Scottish Enlightenment and the End of the Philosophical Society of Edinburgh", The British Journal of History of Science 21 no. 1 (March 1988): 33-66.

19 Emerson. "The Philosophical Society of Edinburgh 1768-1783," 264.

20 Ibidem, 263. 
The interaction between the Scottish scientists, who very often knew each other, facilitated by the activities of the societies led to the incredible development of $18^{\text {th }}$ century Scotland. Analysing the activities of those societies, especially two of them presented in this study, the deeply academic Wise Club on the one hand and the more socially oriented Philosophical Society of Edinburg on the other, shows how important role they played in shaping the new 'enlightened' world.

\section{Bibliography}

Allan, David. Making British Culture: English Readers and the Scottish Enlightenment, 1740-1830. Routledge Studies in Cultural History, 8. London: Routledge, 2008.

De Ridder-Symoens, Hilde. A History of University in Europe: vol. II Universities in Early Modern Europe (1500-1800). Cambridge: Cambridge University Press, 2003.

Emerson, Roger L. Essays on David Hume, Medical Men and Scottish Enlightenment: Industry, knowledge and Humanity. London: Routledge, 2016.

Emerson, Roger L. "Science and the Origins and Concerns of the Scottish Enlightenment." History of Science 26, (1988): 333-366.

Emerson, Roger L. "The Philosophical Society of Edinburgh 1737-1747." The British Journal of History of Science 12, no. 2 (July 1979): 155-191.

Emerson, Roger L. "The Philosophical Society of Edinburgh 1748-1768." The British Journal of History of Science 14, no. 2 (July 1981): 133-176.

Emerson, Roger L. "The Philosophical Society of Edinburgh 1768-1783." The British Journal of History of Science 18, no. 3 (Nov. 1985): 255-303.

Emerson, Roger L. "The Scottish Enlightenment and the End of the Philosophical Society of Edinburgh." The British Journal of History of Science 21 no. 1 (March 1988): 33-66.

Holcomb, Kathleen. "Reid in the Philosophical Society." In The Philosophy of Thomas Reid, edited by Melvin Dalgarno and Eric Matthews, 413-20. Kulwer Academic Publisher, 1989.

Lee Wiley, Margaret. "Gerard and the Scots Societies." Studies in English, no. 20 (1940): 132-136.

Minutes of the Aberdeen Philosophical Society, 1758-1773, edited by Lewis H. Ulman, Aberdeen University Studies, 158. Aberdeen: Aberdeen University Press, 1990.

Rudy, Willis. The Universities of Europe, 1100-1914: A history, 1920. Associated University Press, 1984. 


\section{Summary}

As one of the outstanding researchers of that time, Roger L. Emerson, claims, the phenomenon of the Scottish Enlightenment, called the 'Age of Improvement', is based on 'cosmopolitan learned society'. The Parliamentary Union of 1707 created a unique situation resulting in a significant development and improvement of both the economic and cultural conditions. The 'Age of Improvement' had a few key characteristics. One of them was the development of the science of human nature and natural philosophy. The other one was connected with promoting and spreading that knowledge throughout the Scottish society. The crucial role in cultivating natural sciences was played by universities and numerous specialized societies. What is analysed in this study is the role of philosophical societies in $18^{\text {th }}$ century Scotland. The activities of the Aberdeen Philosophical Society, the Wise Club, and the Philosophical Society of Edinburgh presented in this study shows the important role they played in shaping the new 'enlightened' world.

Keywords: Scottish Enlightenment, philosophical societies, the Aberdeen Philosophical Society, the Wise Club, the Philosophical Society of Edinburg

\section{Streszczenie}

\section{Szkockie oświeceniowe towarzystwa filozoficzne}

Fenomen Szkockiego Oświecenia nazywanego „Wiekiem Doskonalenia” opiera się, jak twierdzi jeden z wybitnych badaczy tego okresu Roger L. Emerson, na „kosmopolitycznym społeczeństwie wiedzy”. Unia Parlamentarna z 1707 roku doprowadziła do powstania unikatowej sytuacji związanej ze znaczącym rozwojem i udoskonaleniem zarówno ekonomicznych, jak i kulturowych warunków w ówczesnej Szkocji. „Wiek doskonalenia” miał kilka kluczowych, charakterystycznych cech, jedną z nich był rozwój nauk o naturze ludzkiej i naturalnej filozofii. Druga - była związana z promowaniem i rozprzestrzenianiem tej wiedzy na całe szkockie społeczeństwo. Kluczową rolę w kultywowaniu nauk przyrodniczych odgrywały uniwersytety i liczne specjalistyczne towarzystwa. Tematem niniejszych analiz jest funkcja towarzystw filozoficznych w XVIII-wiecznej Szkocji. Działalność Towarzystwa Filozoficznego w Aberdeen i Towarzystwa Filozoficznego w Edynburgu przedstawione w tym opracowaniu pokazują znaczenie tych towarzystw w kształtowaniu nowego "oświeconego" świata.

Słowa kluczowe: szkockie oświecenie, towarzystwa filozoficzne, Towarzystwo Filozoficzne w Aberdeen, Towarzystwo Filozoficzne w Edynburgu 